\title{
Review of Ryan Walter's A critical history of the economy: on the birth of the national and international economies. London: Routledge, 2011, 138 pp.
}

\author{
TILL DÜPPE \\ Université du Québec à Montréal
}

During the 18th century, when Britain was virtually in continuous war, the British fleet got part of its naval stores from the Baltic States. This trade was essential for maintaining Britain's military strength. Consequently, when Denmark joined Britain's enemies during the second Anglo-Dutch War and cut off this trade-route, finding a solution to the trade disruption was key for winning the war. Economic wealth and military strength were thought to be the same thing-thus, according to Ryan Walter, early modern man could not conceive of the economy. But when Adam Smith spoke about wealth and thought of labor, and when Ricardo spoke about wealth and thought of class conflicts, Walter argues, the economy was born. Only with the development of "forms of arguments" about trade that remain silent about the strength of the state, can we think of such a thing as the economy.

Walter develops this claim in a book of only 120 pages. It is based on his doctoral thesis at the Centre for the History of European Discourses at the University of Queensland. The book contributes to the Routledge/RIPE Studies in Global Political Economy. According to the editors, the series aims to show "the inseparability of economic from political, social and cultural questions". If the notion of a separate economy is so terribly mistaken, as the folklore of the critique of political economy goes, the critical question to pose is indeed, how did it come about that people began believing so in the first place? And so Walter achieves the opposite of the series' goal: revealing the arguments that made it possible to separate the economic and the political. Why this happened, and whether it was a good thing, as the intended reader of the book series presumably wants to know, is not Walter's concern. He is instead interested in the forms of argument that separate the two domains. He thus presents an epistemic morphology that interrogates the construction of the arguments that make the economy 
"cognizable" as a "nominal field" distinct from the state and a domain in and of its own.

Doing so is more than conceptual history, Walter believes, for he stakes out two positions that make his narrative "critical". He is against the "naturalism" of the economy (the economy is not a natural object that has always been there) and against the "progressivism" of economic science (political economists did not see better, but differently, than other writers before them). Both are obvious requirements for speaking about the birth of the economy. The belief in the existence of a domain of the economy depends on certain "practices of knowing" that play out in certain discursive practices and, ultimately, certain practices of governing. Walter promises to show the reciprocal relation between intellectual arguments and governmental practices. He does not ask whether or not an argument is true, but what it does, what "nominal fields of action" it creates. This allows him to see political economy not as a result of progress, but as emergent from certain "shifts of specific genres of intellectual argument" which remain invisible if one uncritically accepts Whiggish writings of history, such as Smith's distorted account of mercantilism.

The book keeps only some of these promises. Despite his critical intention, Walter's reconstruction of early modern economic writings reasserts much of canonical intellectual history with only little insights into discursive practices. ${ }^{1}$ But before assessing his strategy, it is worth outlining the contents of the work. The book is very neatly organized. The first part describes the intellectual context of the birth of the economy (in early modern British writings on "counsel on trade"). The other three parts explain how this birth took place: one before the economy was conceived; another on its half-way form (Adam Smith); and a last on its final production (David Ricardo). Each of the last three parts is symmetrically divided between a chapter on the national economy and another on the international economy-a division that is thus not itself historicized. In the first two parts, on pre-Smithean writings, Walter goes through a considerable number of pamphlets one by one. The last two parts are closely based on Smith's and Ricardo's canonical texts.

\footnotetext{
${ }^{1}$ The literature to which Walter refers is different from what this reader expected. He refers to Foucault, Polanyi, McKenzie, Tribe, Pocock, and Skinner, but neither to standard texts on early modern thought, such as by Hutchison and Magnusson, nor to historical studies of early modern science, such as by Shapin, Porter, and Poovey.
} 
The first and most descriptive part of the book pleased this reader most. It describes the context in which new forms of arguments could be developed, and also introduces the two main protagonists: the counselor and the statesman. The beginning of the story is well-placed, upon the background of Italian humanism that had just arrived in Britain bringing with it a new virtue for the British governing class"being learned". In order to claim credible interest in the advancement of society one was supposed to be informed. Statesmen and their Privy Council sat together talking over what were the best laws to strengthen the power of the church, of the fleet, and of the merchants. Counselors addressed their advice to statesmen in a respectful, patriarchal fashion. Counsel was neither real debate nor actual command, such that counselors ran into problems with parliamentarians, who also liked to have a word when kings swung their scepters.

When counseling becomes a public affair there are soon others who participate in the discourse-laity, nobles, merchants, and so on-which would make epistemic problems of counsel omnipresent. Recall the work of Steven Shapin (to whom Walter makes no reference), who showed how great the problems of credibility were for the merchant class, as they, for most of Western history, were presumed to make a living by lying (Shapin 1994). Yet Walter did not want to write a book on actual counselors and statesmen since he considers the difference between these two characters only as a "trope" independent of their historical reality. Walter therefore looks closely into the texts to see how the trope of the statesman was little by little replaced by arguments independent of administrative agency. In order to do so, Walter distinguishes between different Genres of Counsel to guide his reconstruction of the "forms of arguments". First, the "analysis of interest" aims at understanding the place of the state in a complex geopolitical situation. Second, "political arithmetic" provides means for estimating the strength of the state, and the share that different trades contribute to it. Third, "counsel on trade" is concerned with identifying the sources and potential for growth. The "object" that can be "cognized" by these three genres is the administrative nation state, but not the economy.

In the second part Walter explores more deeply the argumentative link between state strength and wealth in the counsel on trade genre. He convincingly sketches an image of anxiety in a time of endemic warfare: "Our counselor understood the political world in which the 
state existed as a threatening terrain of ambitious princes and confessional conflict that produced extended wars and uneasy truces" (p. 50). The arguments that evolved in this situation involved, for example, typologies of trade broken down by their effects on the balance of power (for example, fishery was promoted as productive food source for sailors), explanations of the strength of the Dutch (their control of water, extensive fortifications, supply of ships and munitions, and so forth), arguments about colonies as a means for managing the balance of power, and of course the inglorious equation of economic wealth with bullion to pay the army. At a more analytical level, Walter analyzes problems with the circulation metaphor by which trade was conceived as a whole. This part of the book makes a truly original contribution by showing that counsel on trade was its own genre and not only a stopover between sovereignty and political economy.

Only since Smith, Walter argues in part three, have we learned to speak about wealth in a more abstract fashion. Introducing an "analytical wedge" between wealth and strength, Smith was the midwife of the economy, but did not give birth to it. "Critical history" in this part amounts to no more than showing the strategic element in Smith's reconstruction of mercantilist thought, which has been long recognized. Smith, Walter argues, "ignored the geo-political character of counsel on trade and construed its argument as failing to analyze the allocation of capital as set down in his system". Although subverting Smith's rhetorical break with his predecessors, Walter confirms the relative novelty of his arguments and thus the canonical idea of Smith being the founder of political economy-though not quite the founder of the dismal science. His presentation of Smith goes little beyond textbook presentations: wealth is defined with reference to a homogenous category, labor - a definition abstract enough to not immediately lead to thoughts of bullion, munitions, or naval stores. Rather than the statesman, the moral agents of his discourse are individuals acting out of self-love and thereby bringing about an efficient allocation of capital goods. In addition to this static analysis, Smith's theory of capital and the difference between productive and unproductive labor is given space. The military appears no longer as the manifestation of wealth, but as unproductive labor. National security plays the role of an exception to the rule, rather than the main focus of the analysis of wealth. 
Regarding the international economy, Walter argues that Smith indeed conceived of the "nominal object" of the "world economy"- "the whole globe of the earth, of which the wealth, population, and improvement may be either gradually increasing or gradually decaying" (Smith, WN, IV.3.45). Smith thought in terms of one "mass" of world wealth rather than a structure of power enabled by nationally specific sources of wealth. The 'system of natural liberty' results in an optimal allocation of capital directed to overseas trade, an idea that resulted in a new yardstick for national trade policy: neutrality. That was inconceivable in previous writings in counsel on trade as it is insensitive to the balance of power between nations. And so Walter writes justly that with Smith the very genre of counsel on trade begins to degenerate, since a neutral trade policy deprives the counselor of the possibility of actually counseling the statesmen. However, despite this "dislocation of argument in counsel on trade" (p. 91), the implied audience of Smith is still the statesman with the power to increase wealth by specific laws. The traditional role of the statesmen is only "partially eclipsed" (p. 76) by the moral agent.

It was Ricardo, in the early 19th century, who, according to Walter, gave birth to the economy. Again, Walter's presentation differs little from others. He goes through the deduction of the functional distribution of income from the law of diminishing returns in agriculture. The abstract notion of economic "classes" (landlords, capitalists, and workers) was most decisive, according to Walter: "The emergence of class interests founded by distribution represented the most important break with Wealth of Nations and with the preceding forms of argument in counsel on trade" (p. 96). The statesman consequently vanishes from Ricardo's writings altogether and with him the problem of national strength and inter-state rivalry. International trade was a matter of diverging growth paths according to different returns in agriculture.

The humanistic image of counsel offered by a subject to a sovereign was replaced by the imperative to disseminate the scientific insights of political economy to a legislature; Ricardian political economy was not a branch of the statesmen craft, but a science in its own right.

Notably, Ricardo treated the international and the national economy symmetrically, such that there is in fact no analytical difference. 
Indeed, one can only speak of a difference between the national and the international economy if the "nation" supersedes the economic. The difference is political. Walter draws the correct conclusion: "political economy had emerged not only as a science of wealth with little to say about power, but as one that could look dubiously at the very existence of the nation state" (p. 111). But this is also why the difference between the national and international economy should itself be historicized rather than taken for granted, as in this book.

Three questions remain open after reading Walter's book. First, this reader would have liked to learn about the reasons why these forms of arguments emerged. Why was the economy separated from the political? Is it not the task of "contextual intellectual history" to explain why certain arguments emerged at a particular point in time and became, or failed to become, convincing? To be sure, refusing to rule on the truth or falsity of an argument is a first step towards, but still a far cry from, historical criticism. Walter works patiently from text to text but gives relatively little consideration to why these texts succeeded. Ricardo, for example, may have managed to silence much of the statesman trope, but the interesting question is how his argument nevertheless became effective in the political arena. The big topics in historical epistemology, such as credibility and authority, are strikingly absent from Walter's account. How did intellectual arguments emerge from, and affect, historical life? Walter leaves us with a description of intellectual change in which forms of argument emerge and recede without reasons and with no consequences.

Only once one has answered this question, can one address a second open question: what happened to this separation after its initiation? Was it ever fully accomplished? The separation of state and wealth, Walter notes in passing towards the end, could indeed be exploited by both the left and the right. Mill, Marx, Marshall, down to Arrow and Debreu all had their own ways of dividing the economic from the political. We certainly do not think of the economy today as a separate object because we implicitly trust in Ricardo's notion of "classes".

The third open question must be the most pressing for the reader of this book series: what does this birth tell us about the current state of the linkages between the political and the economic? After reading Walter's account, the contemporary folk-belief that the economy is all about power-relations remains a riddle; and likewise the persistent folkjustification for the existence of economic science: that it is "politically 
relevant". In other words, the lessons that can be drawn from Walter's analysis of the forms of arguments that separated the economic from the political remain unclear. In the very last paragraph Walter gives a vague hint. He mentions Afghanistan and Iraq, arguing that the separation between wealth and strength is valuable as they are so closely intermingled in present-day discourse. "The politics economics split provides a valuable ideological function in contemporary political life" (p. 118). It is that "valuable function" about which this reader would have liked to learn more from a book on the birth of the economy.

\section{REFERENCES}

Shapin, Steven. 1994. A social history of truth: civility and science in seventeenth century England. Chicago: University of Chicago Press.

Smith, Adam. 1976 [1776]. An inquiry into the nature and causes of the wealth of nations [WN]. In The Glasgow edition of the works and correspondence of Adam Smith, Vol. 2, eds. R. H. Campbell, and A. S. Skinner. Oxford: Oxford University Press.

Till Düppe is an assistant professor for the history of economics at the Université du Québec à Montréal.

Contact e-mail: <duppe.till@uqam.ca> 